Web Site: https://jutq.utq.edu.iq/index.php/main

Email: journal@jutq.utq.edu.iq

\title{
The positive effect of metformin and metronidazole on the
}

diabetic rats experimentally

Orass Saad Kahyoon

Department of Physiology, College of Veterinary medicine,

University of Thi-Qar

Email: oras-s@ utq.edu.iq

\begin{abstract}
Diabetes mellitus is considering most serious disease of endocrine, it affecting large number of people in worldwide. This study was performed to insured the effect of combination of metformin and metronidazole on disorder in metabolic that concomitant with injection of alloxan IP induced diabetes in rats. In this study forty male rats: divided into four groups including control group G1, alloxn group (150 mg/kg single dose) G2, alloxn group orally treated with metformin (150mg/kg/BW) G3, and alloxn group orally treated with metformin $(150 \mathrm{mg} / \mathrm{kg} / \mathrm{BW})$ and metronidazole $(500 \mathrm{mg} / \mathrm{kg} / \mathrm{BW}) \mathrm{G} 4$. The experiment last for 14 days. The result shows marked increase in MDA, glucose and also in liver enzymes, lipid profiles and even observed disorder in kidney function test by increased in the creatinine, urea, and uric acid levels. In addition to study the histological changes in diabetic liver of rats characterized by kupffer cells activation, dilation and congestion of central vein and hepatic sinusoids. Administration of metformin and combination of metformin and metronidazole, result in significant reduction return abnormal parameters to the normal values. Also correct the abnormal histological changes of liver.
\end{abstract}

Keywords: alloxan, metformin, metronidazole, rats.

\section{الخلاصة}

يعتبر مرض السكري اخطر امر اض الغدد الصح, ويوثر على عدد كبير من الناس في جميع

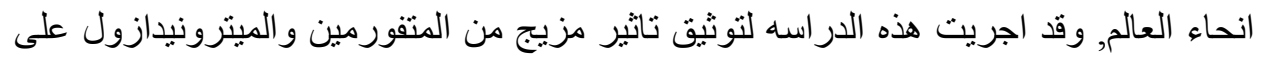
اضظر اب التمثنيل الغذائي في الجرذان المحدثة السكر بعد حقنها بالالوكسان. في هذه الدئن الدراسه 


\section{University of Thi-Qar Journal Vol. 13 No.4 DEC 2018}

Web Site: https://jutq.utq.edu.iq/index.php/main

Email: journal@jutq.utq.edu.iq

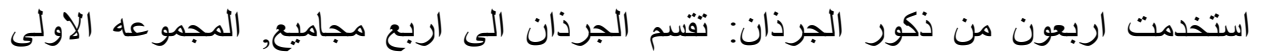

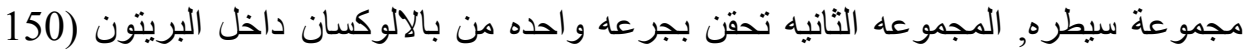

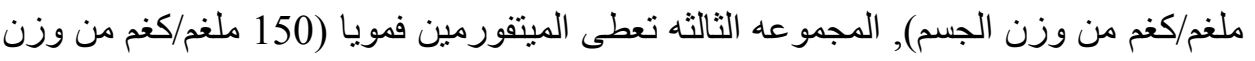

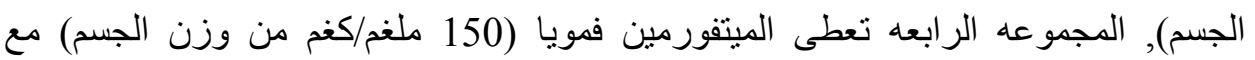

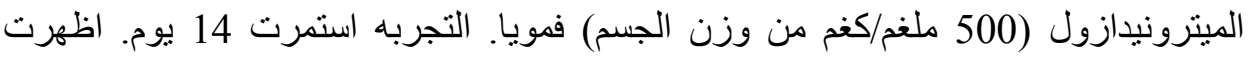

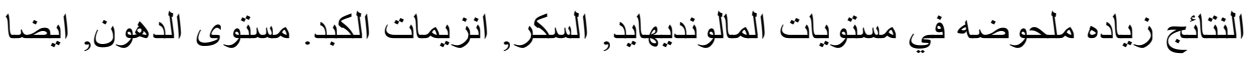

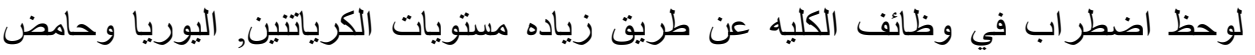

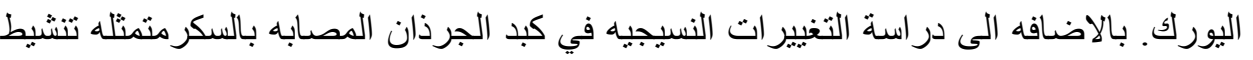

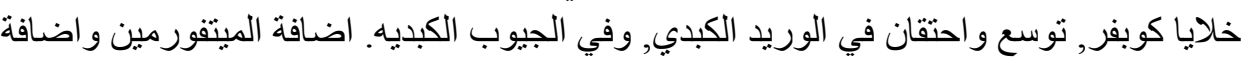

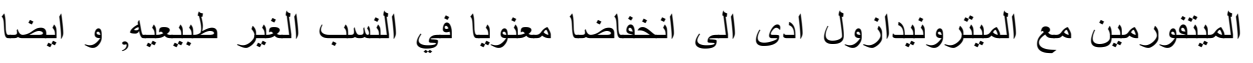

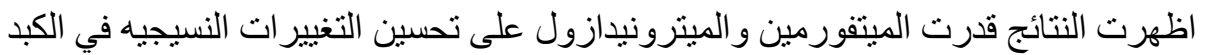

\section{Introduction}

The term diabetes mellitus (DM) is considered as disorder in metabolism of fat, protein carbohydrate, causing increase in blood sugar resulting from defects in insulin secretion, insulin sensitivity or both (WHO, 1999; Baynes, 1999). Also the effect of DM result in dysfunction of many organs. It characteristic by polyuria, thirst, blurring of vision and loss of body weight (WHO, 1999). Also this disorder is associated with profound alterations in lipid profile and with an increased risk of coronary heart disease (Saravanan and Pari, 2006).

Metformin is an only member of biguanide, and generally it is the first-choice oral drugs in the treatment of type $2 \mathrm{DM}$ due to it has potent antihyperglycemic effect, important effect on body weight, and not expensive. Using of other antidiabetic drugs with metformin will produce synergism antidiabetic effect (Standl and Schnell, 2012).

Metronidazole is one of those chemotherapeutic agents that bean have used in treatment of ailments caused by anaerobic bacteria and certain anaerobic protozoa, such as Trichomonas vaginalis, Entamoeba histolytical, and Giardia lamblia (Dean et al., 1989). Metronidazole has been reported to induce a reversible bone marrow depression and cytotoxic effects on male mice fertility (El-Nahas and El-Ashmawy, 2004). Administration of Metronidazole with high doses caused harmful effects on some organs and affects males' fertility in rats (Schwartz et al., 1979; Mudry et al., 2007). With using of Metronidazole, several neurologic side effects may occur, including headache peripheral 


\section{University of Thi-Qar Journal Vol. 13 No.4 DEC 2018 \\ Web Site: https://jutq.utq.edu.iq/index.php/main \\ Email: journal@jutq.utq.edu.iq}

neuropathy, and encephalopathy (Hobson et al., 2006), in addition to gastrointestinal upset, metallic taste and rarely pancreatitis (Nigwekar and Casey, 2004).

The aim of study to investigate the effect of metronidazole on the antidiabetic and antihyperlipidemic effect of metformin in induced diabetes rats, as well as on some tissue markers of oxidative stress (malondialdehyde).

\section{Materials and Methods}

The experiment was conducted at the animal house of the Veterinary Medicine College-University of Basrah, were 40 male rats (Rattus norvegicus) sexually mature of 12 weeks age and 175-200 gram weight were used. These animals were housed in standard cages with controlled temperature $(20-25 \mathrm{oC})$ and 12 hours light / dark cycle with free access to water and standard pellets diet. One week after acclimatization in the laboratory where experiment were performed. The animals were divided randomly into 4 equal groups (10 rats in each group) and treated for 14 days as following: Control group G1: In which rats were treated with normal saline intraperitoneally injected $(0.5 \mathrm{ml} /$ day $)$. Alloxan-induced diabetes group G2: Diabetes was induced by a single intraperitoneal injection of $150 \mathrm{mg} / \mathrm{kg}$ monohydrated alloxan (Sigma, St. Louis, MO, USA) dissolved in sterile 0.9\% saline. Metformin group G3: Diabetes was induced and rats were treated with Metformine/orally/was administered at $150 \mathrm{mg} / \mathrm{kg} / \mathrm{BW} /$ day/ suspended in physiological saline by gavage (Majithiya and Balaraman, 2006). Metformin and Metronidazole group (M+M group) G4: (Diabetes was induced and rats were treated with Metformin/orally at $(150 \mathrm{mg} / \mathrm{kg} / \mathrm{BW} /$ day $)$ (Majithiya and Balaraman, 2006), and treated with Metronidazole/orally at (500 $\mathrm{mg} / \mathrm{kg} / \mathrm{BW} /$ day) suspended in physiological saline by gavage.

After overnight fast, the animals were sacrificed on the 15th day under mild chloroform anesthesia and blood was obtained via cardiac puncture. Blood was collected from the heart by $10 \mathrm{ml}$ disposable syringe of $22 \mathrm{G}$ needles (Parasuraman, et al., 2010). One $\mathrm{ml}$ of blood was transferred into EDTA tube for hematological investigations, the remaining volume of blood transferred into plain tube and centrifuged at $3000 \mathrm{rpm}$ for 15 minutes to obtain the serum which then transferred into Eppendorf tubes and stored at $-20^{\circ} \mathrm{C}$ untill used for measurement of different parameters. 


\section{University of Thi-Qar Journal Vol. 13 No.4 DEC 2018}

Web Site: https://jutq.utq.edu.iq/index.php/main

Email: journal@jutq.utq.edu.iq

\section{Results}

In the diabetic rats there are abnormalities in many parameters, in table (1): there are a significant increasing $(\mathrm{P}<0.05)$ in the MDA and glucose in diabetic group compared with the control group, while in metformin group the increasing in the MDA and glucose levels were reduced significantly $(\mathrm{P}<0.05)$ compared with those in control group and diabetic group. In $\mathrm{M}+\mathrm{M}$ group (metformin and metronidazole group, there are more correction of these parameters with metronidazole present.

Table (1): The ameliorative effects of metformin and metronidazole on alloxan treated rats on MDA and glucose $\mathrm{M}+\mathrm{SE}$

\begin{tabular}{|c|c|c|}
\hline Group & MDA nmol/mL & Glucose mg/dL \\
\hline G1 & $85.62 \pm 2.08 \mathrm{a}$ & $88.3 \pm 0.83 \mathrm{a}$ \\
\hline G2 & $170.5 \pm 1.16 \mathrm{~b}$ & $166.9 \pm 0.84 \mathrm{~b}$ \\
\hline G3 & $140.43 \pm 1.41 \mathrm{c}$ & $101.7 \pm 1.36 \mathrm{c}$ \\
\hline G4 & $100.2 \pm 1.03 \mathrm{~d}$ & $99.5 \pm 0.41 \mathrm{c}$ \\
\hline LSD & 17.1 & 2.27 \\
\hline
\end{tabular}

The obtained results in Table (2) revealed that the administration of alloxan was associated with significant increase $(\mathrm{P}<0.05)$ in serum ALT, AST and ALP levels when compared with the control group. The elevation in serum level of the enzymes was nonsignifecantly reduced from those in control group by administration of Metformin. While administration metformin plus metronidazole resulted in significant reduction $(\mathrm{P}<0.05)$ in serum ALT and AST when compared with alloxan and metformin group.

Table (2): The ameliorative effects of metformin and metronidazole on alloxan treated rats on liver enzymes $\mathrm{M}+\mathrm{SE}$

\begin{tabular}{|c|c|c|c|}
\hline Group & ALT(U/L) & AST(U/L) & ALP (IU/L) \\
\hline G1 & $9.3 \pm 0.7 \mathrm{a}$ & $17.4 \pm 0.09 \mathrm{a}$ & $\begin{array}{c}50.5 \pm 0.24 \\
\mathrm{a}\end{array}$ \\
\hline G2 & $20.5 \pm 0.14 \mathrm{~b}$ & $43.8 \pm 0.12 \mathrm{~b}$ & $\begin{array}{c}90.9 \pm 0.27 \\
\mathrm{~b}\end{array}$ \\
\hline G3 & $13.4 \pm 0.11 \mathrm{c}$ & $22.5 \pm 0.02 \mathrm{c}$ & $66.8 \pm 0.18$ \\
\hline
\end{tabular}


University of Thi-Qar Journal Vol. 13 No.4 DEC 2018

Web Site: https://jutq.utq.edu.iq/index.php/main

Email: journal@jutq.utq.edu.iq

\begin{tabular}{|c|c|c|c|}
\hline & & & $\mathrm{c}$ \\
\hline G4 & $10.7 \pm 0.10 \mathrm{a}$ & $19.5 \pm 0.03 \mathrm{a}$ & $\begin{array}{c}54.9 \pm 0.14 \\
\mathrm{~d}\end{array}$ \\
\hline LSD & 1.39 & 2.12 & 4.38 \\
\hline
\end{tabular}

The results in Table (3) revealed that the administration to alloxan cause significant increased $(\mathrm{P}<0.05)$ in $\mathrm{TC}, \mathrm{TG}, \mathrm{LDL}$ and VLDL and significant decreased in HDL values compared with the control group. Also administration of metformin led to decline significantly $(\mathrm{P}<0.05)$ in $\mathrm{TG}$ and decreasing significantly in TC, LDL and VLDL values compared with alloxan treated group, but TC, TG, LDL still higher than those of control value. While HDL shows decreased insignificantly compared with control group. Administration of $\mathrm{M}+\mathrm{M}$ in four group result in return the parameters nearly to normal value.

Table (3): The ameliorative effects of metformin and metronidazole on alloxan treated rats on lipid profiles $\mathrm{M}+\mathrm{SE}$

\begin{tabular}{|c|c|c|c|c|c|}
\hline $\begin{array}{c}\text { Grou } \\
\mathrm{p}\end{array}$ & TC mg/Dl & TG mg/dL & $\begin{array}{c}\text { HDL } \\
\mathrm{mg} / \mathrm{dL}\end{array}$ & $\begin{array}{c}\text { VLDL } \\
\mathrm{mg} / \mathrm{dL}\end{array}$ & $\begin{array}{c}\mathrm{LDL} \\
\mathrm{mg} / \mathrm{dL}\end{array}$ \\
\hline $\mathrm{G} 1$ & $\begin{array}{c}55.83 \pm 1.84 \\
\mathrm{a}\end{array}$ & $73.76 \pm 0.5 \mathrm{a}$ & $\begin{array}{c}51.62 \pm 0.1 \\
3 \mathrm{a}\end{array}$ & $\begin{array}{c}18.2 \pm 0.76 \\
\mathrm{a}\end{array}$ & $\begin{array}{c}45.7 \pm 0.14 \\
\mathrm{a}\end{array}$ \\
\hline $\mathrm{G} 2$ & $\begin{array}{c}82.82 \pm 4.33 \\
\mathrm{~b}\end{array}$ & $\begin{array}{c}103.52 \pm 0.4 \\
3 \mathrm{~b}\end{array}$ & $\begin{array}{c}33.62 \pm 0.2 \\
2 \mathrm{~b}\end{array}$ & $\begin{array}{c}28.24 \pm 0.8 \\
5 \mathrm{~b}\end{array}$ & $\begin{array}{c}78.38 \pm 0.1 \\
5 \mathrm{~b}\end{array}$ \\
\hline $\mathrm{G} 3$ & $67.36 \pm 4.8 \mathrm{c}$ & $\begin{array}{c}78.78 \pm 0.21 \\
\mathrm{c}\end{array}$ & $\begin{array}{c}48.7 \pm 0.17 \\
\mathrm{c}\end{array}$ & $\begin{array}{c}15.7 \pm 0.12 \\
\mathrm{c}\end{array}$ & $\begin{array}{c}48.9 \pm 0.04 \\
\mathrm{c}\end{array}$ \\
\hline $\mathrm{G} 4$ & $\begin{array}{c}55.15 \pm 2.42 \\
\mathrm{a}\end{array}$ & $\begin{array}{c}75.64 \pm 0.43 \\
\mathrm{~d}\end{array}$ & $\begin{array}{c}51.14 \pm 0.3 \\
5 \mathrm{~d}\end{array}$ & $\begin{array}{c}19.8 \pm 0.07 \\
\mathrm{~d}\end{array}$ & $\begin{array}{c}47.18 \pm 0.1 \\
4 \mathrm{~d}\end{array}$ \\
\hline LSD & 11.97 & 1.88 & 2.41 & 0.98 & 1.47 \\
\hline
\end{tabular}

Table (4) illustrated the effect of metformin and metronidazole on serum level of creatinine, urea and uricacid in rats given alloxan and compared with control group value. Injection of alloxan caused a significant increment $(\mathrm{P}<0.05)$ in serum level of creatinine, urea and in 


\section{University of Thi-Qar Journal Vol. 13 No.4 DEC 2018 \\ Web Site: https://jutq.utq.edu.iq/index.php/main \\ Email: journal@jutq.utq.edu.iq}

uric acid values. Administration of metformin led to decline significantly $(\mathrm{P}<0.05)$ in serum level of creatinine, urea and in uric acid values value compared with alloxan treated group, and it reached to normal values compared with the control value, while in metronidazole group these parameters are return to the normal values when compared with control group.

Table 4: The ameliorative effects of metformin and metronidazole on alloxan treated rats on serum level of creatinine, urea, uric acid $\mathrm{M} \pm \mathrm{SE}$

\begin{tabular}{|c|c|c|c|}
\hline Group & Creatinine & Urea mg/dL & $\begin{array}{c}\text { Uric acid } \\
\mathrm{mg} / \mathrm{Dl}\end{array}$ \\
\hline G1 & $0.26 \pm 0.002 \mathrm{~b}$ & $32.34 \pm 0.27 \mathrm{a}$ & $3.1 \pm 0.02 \mathrm{a}$ \\
\hline G2 & $0.71 \pm 0.004 \mathrm{a}$ & $37.9 \pm 0.16 \mathrm{~b}$ & $3.84 \pm 0.01 \mathrm{~b}$ \\
\hline G3 & $0.41 \pm 0.004 \mathrm{~b}$ & $35.02 \pm 0.08 \mathrm{c}$ & $3.32 \pm 0.02 \mathrm{c}$ \\
\hline G4 & $0.27 \pm 0.006 \mathrm{a}$ & $33.88 \pm 0.14 \mathrm{a}$ & $3.4 \pm 0.02 \mathrm{a}$ \\
\hline LSD & 0.014 & 1.14 & 0.1 \\
\hline
\end{tabular}

\section{Histopathological changes in the liver $(1,2,3,4)$}

Normal hepatic structure is shown from liver of control rats. In which, normal hepatocytes are arranged in cords radiating from the central hepatic vein and separated by normally looking hepatic sinusoids (Fig: 1). Whereas in Fig: 2, the liver of rats in alloxan group showed Kupffer cells activation, dilation and congestion of central vein and hepatic sinusoids that due to alloxan administration, while diabetic control group showed high level of cellular abnormalities including necrosis, cellular and vascular degeneration, vascular congestion, hyperplasia of the hepatocytes and vacuolation, these disorders is treated with metformin administration (Fig: 3). These effects of metformin is supported with administration of metronidazole (Fig: 4) 


\section{University of Thi-Qar Journal Vol. 13 No.4 DEC 2018 \\ Web Site: https://jutq.utq.edu.iq/index.php/main Email: journal@jutq.utq.edu.iq}

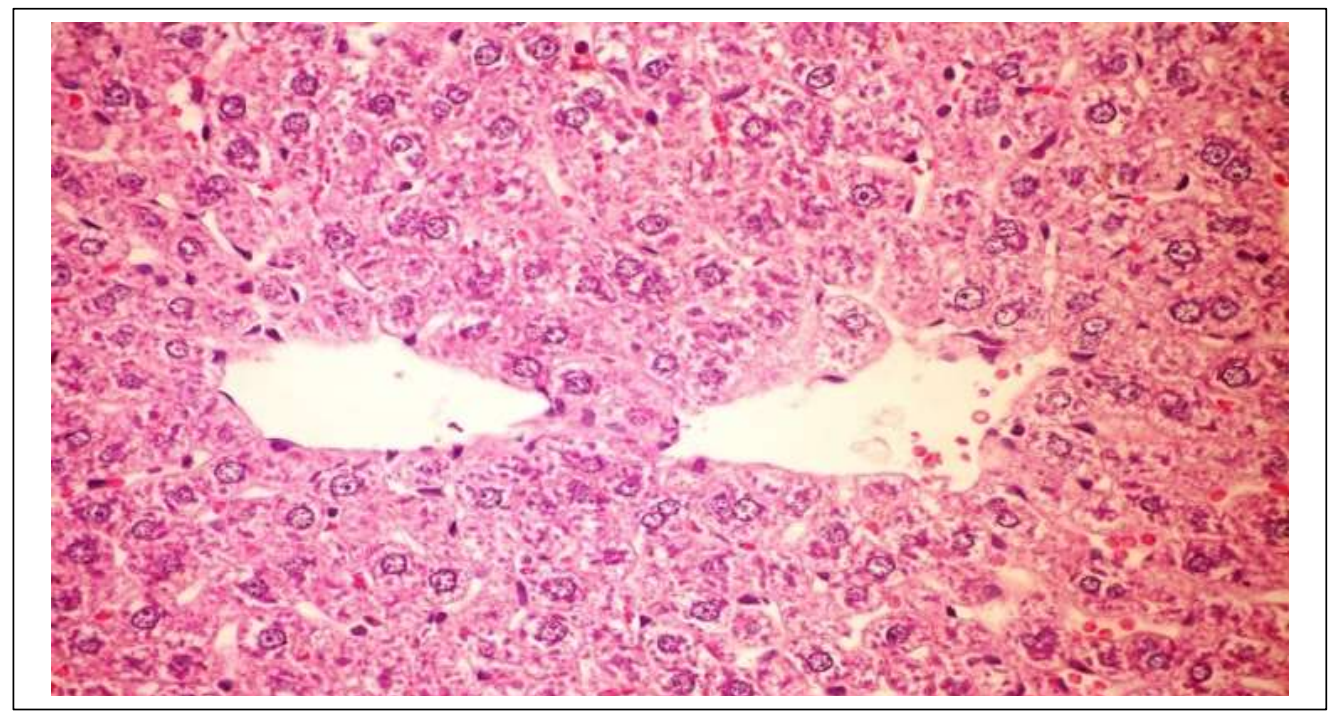

Figure 1: Liver of normal control rat showing the normal histological structure of central vein (star), and hepatocyte (black arrow) (H\&E x 400)

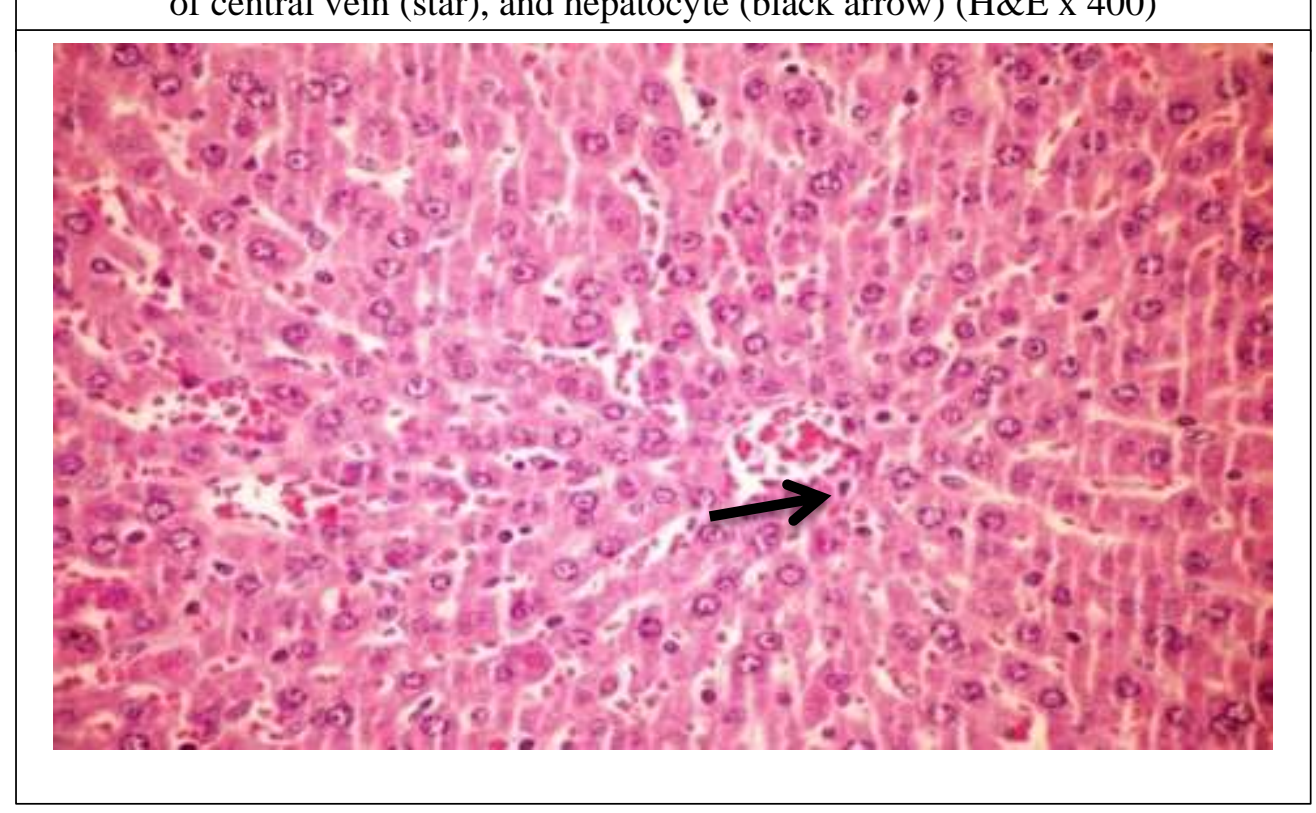

Figure 2: Liver of diabetic rat showing Kupffer cells activation, dilation and congestion of central vein and hepatic sinusoids in black arrow (H\&E x 


\section{University of Thi-Qar Journal Vol. 13 No.4 DEC 2018 \\ Web Site: https://jutq.utq.edu.iq/index.php/main \\ Email: journal@jutq.utq.edu.iq}

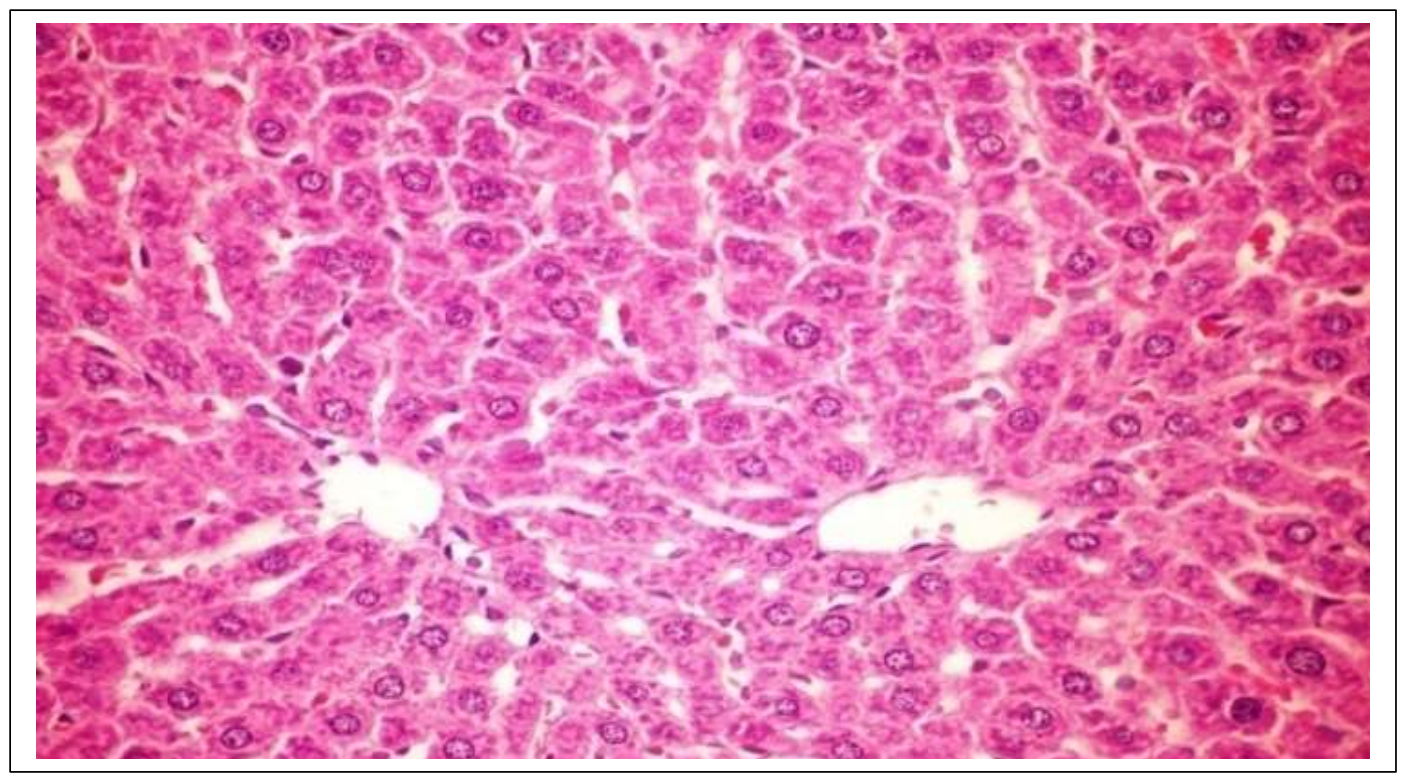

Figure 3: Liver section of diabetic rats treated with metformin alone showing nearly normal structures (H\&E x 400)

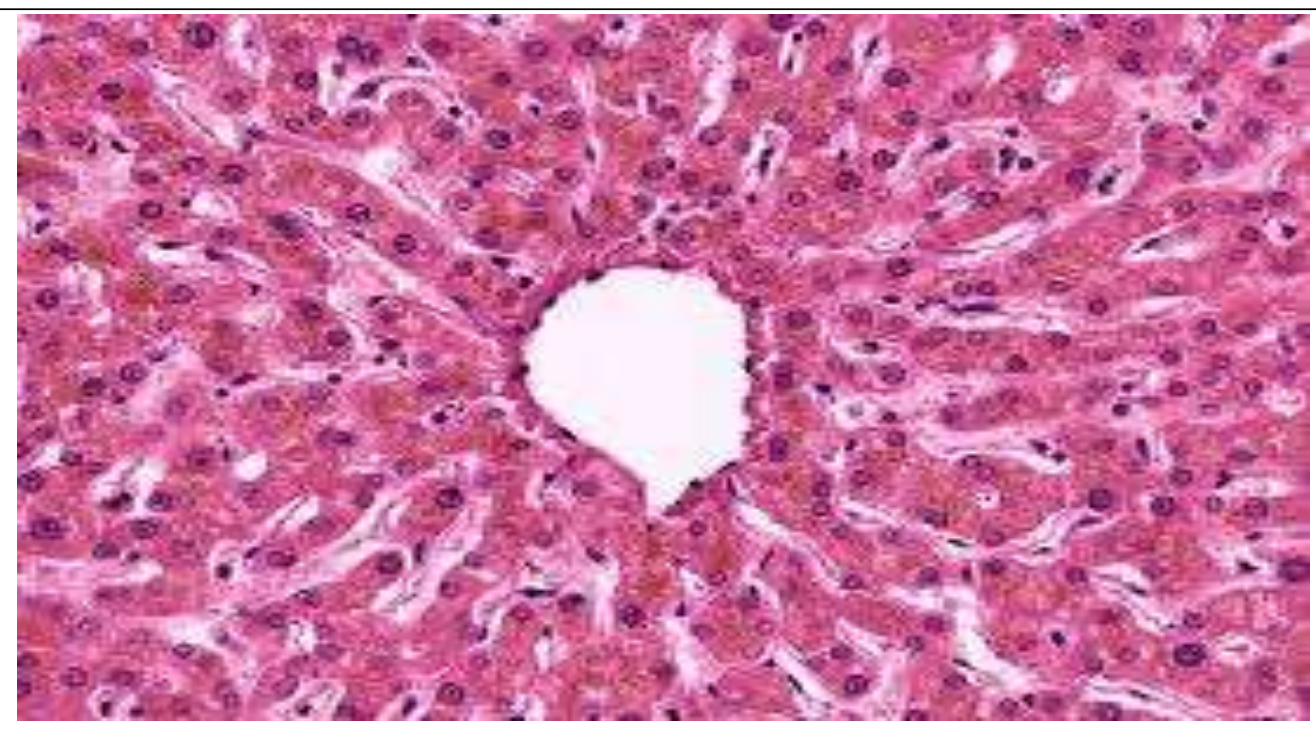

Figure 4: Liver section of diabetic rats treated with metformin + metronidazole, showing nearly normal structures (H\&E x 400) 


\section{Discussion}

Diabetes mellitus is a chronic metabolic disorder involving carbohydrate, proteins and fat characterized by hyperglycemia and insufficiency secretion or action of endogenous insulin (Barar, 2002).

In diabetes mellitus, oxidative stress seems mainly to be due to increased production of free radicals and/or a sharp reduction of antioxidant defenses (Ahmed, 2005). Alloxan is one of the usual substances used for the induction of diabetes mellitus apart. It has a destructive effect on the beta-cells of the pancreas (Prince and Menon, 2000; Jelodar et al., 2003; Gwarzo et al., 2010), and the product of its reduction, dialuric acid, establish a redox cycle with the formation of superoxide radicals. These radicals undergo dismutation to hydrogen peroxide with simultaneous massive increase in cystolic calcium concentration, which causes rapid destruction of pancreatic beta-cells of Islets of Langerhans thereby inducing hyperglycemia (Grover et al., 2000; Szudelski, 2001). Insulin deficiency leads to various metabolic alterations in the animals such as increased blood glucose, total cholesterol, alkaline phophatase and transaminases (Begum and Shanmudnaram, 1978). Also the destruction of pancreatic beta cells is by alloxan cause release or increase level of Malondialdehyde (MDA) which is a degradative product of peroxidation of polyunsaturated fatty acids (PUPA) in the cells membrane. Presence of higher MDA in the serum is an indication of induced lipid peroxidation and of oxidative stress of which has been reported as one of the underlying cause of diabetes mellitus (Akinosun and Bolajoko, 2007). Liver enzymes such as AST and ALP are marker enzymes for liver function and integrity (Adaramoye, 2008). In this study, increased activities of AST and ALT were observed in the diabetic animals. Hence it indicates that diabetes may induce hepatic dysfunction in rat. The increase in the level of these enzymes in diabetes may be as a result of leakage from the tissues and migration into the bloodstream (Chaudary et al., 1993). Diabetic patients may have damage to various tissues. The damage can increase serum level of ALT and AST. Levels of ALT may rise sharply if there is injury to hepatocytes, cardiac muscle, striated muscle, pancreas, kidney and erythrocytes. Serum level of AST wills increases when hepatocytes, cardiac muscle, striated muscle, and pancreas have damage (Keeffe and Friedman 2004). Excess of fatty acids in plasma produced by the alloxan-induced diabetes promotes the liver conversion of some fatty acids into triacylglycerol, phospholipids and 


\section{University of Thi-Qar Journal Vol. 13 No.4 DEC 2018 \\ Web Site: https://jutq.utq.edu.iq/index.php/main \\ Email: journal@jutq.utq.edu.iq}

cholesterol which may be discharged into the blood as lipoproteins (Bopanna et al., 1997). The main function of the kidneys is to excrete the waste products of metabolism and to regulate the body concentration of water and salt. Significant increase of total urea and creatinine levels indicated impaired renal function of diabetic rats which led to a negative nitrogen balance, enhanced proteolysis and lowered protein synthesis (Sulaiman et al., 2012)

Treatment of diabetic rats with metformin for 14 days showed a decrease in the elevated plasma MDA level which might indicate that metformin has a radical scavenging activity (Murad et al., 2015), and has protective effect against the hepatotoxicity produced by alloxan diabetes by decreased blood glucose levels, serum ALT and AST activities, total lipid. (Yanardag et al., 2005). Metformin is an oral hypoglycaemic agent that exhibits an antihpyerglycemic effect devoid of insulin release (Stumvoll et al., 1995). Metformin exerts its major effect through inhibition of hepatic glucose production; enhanced glucose disposal has also been described. Some early studies suggested that metformin exerts its insulin-sensitising effect (Bailey and Puah, 1986) and/or promotes glucose transport independently of the insulin receptor-mediated proximal signalling pathway in skeletal muscle (Hundal et al., 1992; Zhou et al., 2001; Turban et al., 2012). Also metronidazole were used in this study which is an antibiotic used in treatment of many anaerobic bacterial and protozal infection. It is rapidly absorbed from the digestive system (Turgut and Özyazici, 2004).

In this study, concomitant administration of metformin with metronidazole to diabetic result in improvement in abnormal parameters. Metronidazole may increase in the absorption rate constant, peak plasma concentration of metformin, increased the bioavailability and decrease in elimination rate constant of metformin. This potentiated effect of metronidazole to metformin is agreement with the report of the study carried out by Bakare-Odunola et al., (2001), also Abdullahi, 2015 reported the potentiation effects on metformin was observed with concomitant administration of a single dose of $1 \mathrm{~g}$ metformin with 400 $\mathrm{mg}$ of metronidazole tablets and $1 \mathrm{~g}$ ampiclox capsules by increasing the peak plasma concentration of metformin.

Also alloxan caused congestion of central vein of liver with marked expantion of sinusoidal spaces, pyknosis of nuclei of hepatocytes (Bollen et al., 1998). After administration of metformin, there is a 


\section{University of Thi-Qar Journal Vol. 13 No.4 DEC 2018 \\ Web Site: https://jutq.utq.edu.iq/index.php/main \\ Email: journal@jutq.utq.edu.iq}

histopathological assessment of liver tissues confirmed the membrane stabilizing and cytoprotective potential against the toxic manifestations induced by alloxan (Kanchan et al., 2012), which more improved with concomitant administration with metronidazole.

Conclusion includes protective effect of metformin against DM in rats induced by alloxan and potentiates this effect with concomitant administration with metronidazole.

\section{References}

Abdullahi, G.M. (2015). Effects of ampiclox (ampicillin/cloxacillin), metronidazole and amoxicillin on the pharmacokienetics of metformin in type 2 diabetic patients. Pp: 103.

Adaramoye, O.A.; Osaimoje, D.O.; Akinsanya, M.A.; Nneji, C.M.; Fafunso, M.A. and Ademowo, O.G. (2008). Changes in antioxidant status and biochemical indices after acute administration of artemether, artemether-lumefantrine and halofantrine in rats. Authors J. Compilation: Basic Clin. Pharmacol. Toxicol., 102: 412- 418.

Ahmed, B.G. (2005). The physiological and biochemical effects on the balance between oxidative stress and antioxidant defense systems. Rev. Med. J. Islamic World Acad. Sci., 15: 34-42.

Akinosun, O.M. and Bolajoko, E.B. (2007). Total Antioxidant Status in Type II Diabetic Patients. Niger J. Clin. Pra.;10(2):126-129.

Bailey, C.J. and Puah, J.A. (1986). Effect of metformin on glucose metabolism in mouse soleus muscle. Diabetes Metab 12:212-218.

Bakare-Odunola, M.T.; Garba, M.; Enemali, S.I.; Okeniyi, S.O. and Gebi, J. (2001). The influence of ampicillin/cloxacillin on the pharmacokinetics of chlorpropamide in Type 2 diabetic Patients. West African Journal of pharmacology. Drug Research 17: (1and 2) 74-76.

Barar, F.S.K., (2002). Essentials of Pharmaco Therapeutic. 3rd Edn., S. Chand and Company Ltd., New Delhi.

Baynes, Y.W. (1999). Thorpe R. Role of oxidative stress in diabetic complications. Diabetes 1999; 48: 1- 9.

Begum, N. and Shanmudnaram, K.R. (1978). Tissue phosphates in experimental diabetes Arogya. J. Health Sci., 4: 129-139. 


\section{University of Thi-Qar Journal Vol. 13 No.4 DEC 2018 \\ Web Site: https://jutq.utq.edu.iq/index.php/main \\ Email: journal@jutq.utq.edu.iq}

Bollen, M.; Keppens, S. and Stalmans, W. (1998). Specific features of glycogen metabolism in the liver. Biochem J. 336: 19-31.

Bopanna, K. N.; Kannan, J.; Sushma, G.; Balaraman, R. and Rathod, S. P. (1997). Antidiabetic and antihyperlipidaemic effects of neem seed kernel powder on alloxan diabetic rabbits. Indian J. Pharmacol.,29: 162167.

Chaudary, A. R.; Alam, M. and Ahmad, M. (1993). Studies on medicinal herbs II. Effect of Colchicum luteum on biochemical parameters of rabbit serum. Fitoterapia. 64 : 510-515.

Dean, H. J.; Cornacoff, B.J.; Rosenthal, J. G.; Luster, I. (1989). Immune System: Evaluation of Injury. In; Hayes AW, Editor. Principles and Methods of Toxicology. New York: Raven Press.

El-Nahas, A. F.; El-Ashmawy, I. M. (2004). Reproductive and cytogenetic toxicity of metronidazole in male mice. Pharmacol Toxicol 2004; 5:226-31.

Grover, J.K.; Vats, V. and Rathi, S.S. (2000). Antihyperglycemic effects of Eugenia Jambulana and Tinospora Cordifolia in experimental diabetes and their effects on the key metabolic enzymes involved in carbohydrate metabolism. J. Ethnopharmacol., 73: 461-470.

Gwarzo, M.Y.; Nwachukwu, V.A. and Lateef, A.O. (2010). Prevention of alloxan induced diabetes mellitus in rats by Vitamin A dietary supplementation. Asia J. Ann. Sci.;4:190-196.

Hundal, H.S.; Ramlal, T.; Reyes, R.; Leiter, L.A. and Klip, A. (1992). Cellular mechanism of metformin action involves glucose transporter translocation from an intracellular pool to the plasma membrane in L6 muscle cells. Endocrinology 131:1165-1173.

Jelodar, G.; Mohsen, M. and Shahram, S. (2003). Effect of Walnut leaf, Coriander and Pomegranate on blood glucose and hispathology of pancreas of Alloxaninduced diabetic rats. Afri. J. Traditional Complementary Altern. Med., 3: 299-305.

Kanchan, D.B.; Subhas, L.B.; Jayshree, S.D. and Jugeet, K.K. (2012). Hepatorenal Repercussions of Alcoholic Exposure in a Rat Model: a Dose-Dependent Study of Metformin Intervention. Iranian Biomedical Journal 16 (2): 101-106. 


\section{University of Thi-Qar Journal Vol. 13 No.4 DEC 2018 \\ Web Site: https://jutq.utq.edu.iq/index.php/main Email: journal@jutq.utq.edu.iq}

Keeffe, E.B., and Friedman, L.M. (2004). Handbook of liver diseases. Edinburgh: Churchill Livingstone, London. 104-123.

Majithiya, J.B. and Balaraman, R. (2006). Metformin reduces blood pressure and restores endothelial functions in aorta os streptozotocininduced diabetic rats. Life Sci. 78 (22): 2615-24.

Mudry, M.D.; Palermo, A.M. and Carballo, M.A. (2007). Metronidazole-induced alterations in murine spermatozoa morphology. Reprod. Toxicol. 23(2):246-52.

Murad, H. A. S.; Saleh, H. A.; Abdulaziz, G.S. and Ali, S.S. (2015). Effect of metformin and pioglitazone on $\beta$-catenin and biochemical markers in sitagliptin-induced pancreatitis in diabetic rats. International Journal of Diabetes in Developing Countries. Volume 35, Issue 3: 332339.

Nigwekar, S.U. and Casey, K.J. (2004). Metronidazole induced pancreatitis. A case report and review of literature," Journal of the Pancreas. 6(5):516-9.

Parasuraman, S.; Raveendran, R. and Kesavan, R. (2010). Blood sample collection in small laboratory animals. J Pharmacol Pharmacother.1 (2):87-93.

Prince, S.M. and Menon, V.P. (2000). Hypoglycemic and other related actions of Tinospora Cardifolia roots in alloxan induced diabetic rats. J. Ethnopharmacol., 70: 9-15.

Saravanan, R. and Pari, L. (2006). Effect of a novel insulinotropic agent, succinic acid monoethyl ester, on lipids and lipoproteins levels in rats with streptozotocinnicotinamide- induced Type 2 diabetes. Journal of Biological Science. 31(5):581-587.

Schwartz, D.E.; Jordan, J.C.; Vetter, W. and Oesterhelt, G. (1979). Metabolic studies of ornidazole in the rat in the dog and in man. Xenobiotica 9:571-81.

Standl, E. and Schnell, O. (2012). Alpha-glucosidase inhibitors cardiovascular considerations and trial evaluation. Diab Vasc Dis Res. 9(3):163-9. doi: 10.1177/1479164112441524.

Stumvoll, M.; Nurjaham, N.; Perriello, G.; Dailey, G. and Gerich, J.E. (1995). Metabolic effects of metformin in noninsulin dependent diabetes mellitus. N Engl J Med. 333: 550-554. 


\section{University of Thi-Qar Journal Vol. 13 No.4 DEC 2018 \\ Web Site: https://jutq.utq.edu.iq/index.php/main \\ Email: journal@jutq.utq.edu.iq}

Sulaiman, G.M.; Ahmed, A.H.; Abbas, A.M. and Ali, A.A. (2012). The Effect of Cherry Sticks Extract on the Levels of Glycoproteins in Alloxan-Induced Experimental Diabetic Mice. Ann. Clin. Lab. Sci.,42(1):34-41.

Szudelski, T. (2001). The mechanism of Alloxan and Streptozotocin action in beta-cells of the rats pancreas. Physiol. Res., 50: 536-546.

Turban, S.; Stretton, C. and Drouin, O. (2012). Defining the contribution of AMPK and PKCs in the regulation of glucose uptake by metformin in skeletal muscle cells. J Biol Chem 287:20088-20099.

Turgut, E.H. and Özyazici, M. (2004). Bioavailability File: Metronidazole. FABAD J. Pharm. Sci., 29, 39-49, 2004. SCIENTIFIC REVIEW.

WHO: 1999. Definition, diagnosis and classification of diabetes mellitus and its complications. World Health Organization, Department of Nonncomunicable Disease Surveillance. (http://whglibdoc.who.int/hg/1999/WHO-NCD-NCS-99.2pdf). 60 pp, Retrieved on 7/6/2007.

Zhou, G.; Myers, R. and Li, Y. (2001). Role of AMP-activated protein kinase in mechanism of metformin action. J Clin Invest 108:1167-1174.

Yanardag, R.1.; Ozsoy-Sacan, O.; Bolkent, S.; Orak, H. and Karabulut-Bulan, O. (2005). Protective effects of metformin treatment on the liver injury of streptozotocin-diabetic rats. Hum Exp Toxicol. Mar;24(3):129-35. 